\title{
Worthwhile Supplemental Reading for Psychiatrists-In-Training
}

A. Kenneth Fuller, MD

Follow this and additional works at: https://jdc.jefferson.edu/jeffjpsychiatry

Part of the Psychiatry Commons

Let us know how access to this document benefits you

\section{Recommended Citation}

Fuller, MD, A. Kenneth (1987) "Worthwhile Supplemental Reading for Psychiatrists-In-Training," Jefferson Journal of Psychiatry. Vol. 5 : Iss. 1 , Article 12.

DOI: https://doi.org/10.29046/JJP.005.1.013

Available at: https://jdc.jefferson.edu/jeffjpsychiatry/vol5/iss $1 / 12$

This Article is brought to you for free and open access by the Jefferson Digital Commons. The Jefferson Digital Commons is a service of Thomas Jefferson University's Center for Teaching and Learning (CTL). The Commons is a showcase for Jefferson books and journals, peer-reviewed scholarly publications, unique historical collections from the University archives, and teaching tools. The Jefferson Digital Commons allows researchers and interested readers anywhere in the world to learn about and keep up to date with Jefferson scholarship. This article has been accepted for inclusion in Jefferson Journal of Psychiatry by an authorized administrator of the Jefferson Digital Commons. For more information, please contact: JeffersonDigitalCommons@jefferson.edu. 


\title{
Worthwhile Supplemental Reading for Psychiatrists-In-Training
}

\author{
MODERN SYNOPSIS OF COMPREHENSIVE TEXTBOOK OF \\ PSYCHIATRY/IV
}

Harold I. Kaplan and Benjamin J. Sadock, 4th ed.

Baltimore, Williams \& Wilkins, 1985 , 937 pages, $\$ 38.50$

\begin{abstract}
STUDY GUIDE AND SELF-EXAMINATION REVIEW FOR MODERN SYNOPSIS OF COMPREHENSIVE TEXTBOOK OF PSYCHIATRY/IV Harold I. Kaplan and Benjamin J. Sadock, 2nd ed. Baltimore, Williams \& Wilkins, 1985,551 pages, $\$ 22.95$
\end{abstract}

\section{A. Kenneth Fuller, M.D.}

The appearance of a fourth edition of this popular text speaks on its own behalf of a successful series. For readers unacquainted with the work, the Modern Synopsis and the Study Guide comprise two-thirds of a three-part series that also includes the full-length, encyclopedic Comprehensive Textbook of Psychiatry/IV, a 2,054-page work edited by Drs. Kaplan and Sadock with nearly 200 contributors, all of whom are authorities in their fields. According to its authors, the Modern Synopsis ". . . is a rewritten distillation of the three previous editions of the Comprehensive Textbook and the Modern Synopsis" (p. vii). While acknowledging that the Modern Synopsis is heavily based on the larger book, Drs. Kaplan and Sadock maintain that it ". . . is not simply a summary but is a companion volume to be used as a supplementary text by medical students, psychiatric residents, residents in other areas of medicine, practicing psychiatrists, and workers in related behavioral fields"' (p. vii).

The single volume, Modern Synopsis, offers a number of advantages: brevity (937 pages), portability (a flexible, lightweight, albeit paper, binding), and a reasonable price. Designed chiefly for medical students, psychiatrists-intraining, and those seeking introductory information about psychiatric topics, the Modern Synopsis serves admirably as a condensed version of the larger standard text. While the references at the end of each chapter are not comprehensive or completely up-to-date, each bibliography contains a group of classic references for further reading.

Readers of previous editions will note the addition of new sections and the deletion of others. Several chapters are retained with very few, if any, changes. 
The chapters vary in quality and suffer from a problem common to all synopses, namely, a loss of elaboration and relevancy resulting from the condensed format. A major flaw of this book is its dogmatic adherence to the nosology of the Diagnostic and Statistical Manual of Mental Disorders (DSM-III). Undeniably, the reader should be exposed to the official American classification system, however, the framework of the DSM-III serves to limit some of the discussions. The chapter devoted to personality disorders, and, to a lesser degree the chapter on neurotic disorders, offer little more than a listing of the features from the DSM-III. At times I felt the authors were about to discuss psychoanalytic derivatives or a novel theoretical formulation, only to be disappointed with their rigid return to descriptive nosology.

Despite these limitations, there is an excellent blending of current scientific information with practical clinical applications. In those areas which I consider myself to be reasonably informed, the topics appeared to be adequately, although superficially, covered. In areas where my knowledge is more limited, I found the book to be informative and enlightening. This served as a reminder to me that, just as no single individual can master all of psychiatry, a synoptic book cannot provide comprehensive coverage of all areas of psychiatry.

The accompanying study guide is designed as a review manual for medical students, newly practicing psychiatrists, and other clinicians who are reviewing for examinations such as the National Board of Medical Examiners (NBME), the Federation of Licensing Examination (FLEX), or the American Board of Psychiatry and Neurology (ABPN). The Study Guide, in my opinion, would be most useful for this purpose.

This review manual is in its second edition and now contains 1,171 multiple-choice questions. The most helpful feature of the Study Guide is the discussion and analysis of both the correct and incorrect test answers. Additionally, key phrases are italicized in order to emphasize the main point of the question. The reader is also given the exact page in the Modern Synopsis on which the material is covered. Numerous tables present diagnostic criteria, associated features and differential diagnosis. References are included at the end of each chapter.

My criticisms of the Study Guide are few. They include the narrow sampling of topics in some sections, the rather glib overview introducing each chapter, and the excessive redundancy in concept definition. Lists of important items and tables provide the necessary information, but they do not convey the relative importance of the various items.

The Study Guide in itself is valuable; used as a companion to the Modern Synopsis (as it was intended), it becomes a highly valuable resource for medical students and psychiatric residents. The clinician will also find them helpful for an occasional quick reference and examination review. The new editions of these two handy and effective volumes should retain their authoritative position within the profession as useful tools of reference. 